\title{
The Metaphysic Communication of Javanese Elite- Public in The Middle of Disruption Era
}

\author{
Sahid Teguh Widodo \\ Universitas Sebelas Maret, Surakarta, Indonesia \\ \{sahidteguhwidodo@yahoo.com\}
}

\begin{abstract}
Metaphysical communication - for some Javanese society - can be understood simply as communication that raises the reality of communication at a high and important level. Javanese culture develops metaphysical communication patterns that are reflected in the language which are still often found in proverbs or figurative words. This paper aims to reveal the form of metaphysical communication into two groups of discussion. First, to reveal the perspective of Javanese communication that comes from its essence, terms and basis for justification, as well as the value of activity seen by the human senses. Second, to determine the implementation of metaphysical communication and to find alternative solutions in case of communication failure between the public-elite. The source of the writing is obtained from textual data in the form of Javanese aphorisms from various sources of old books and documents. The data were analyzed using content analysis methods and theories. Thus, the preparation of this paper is included in library research. The results of this study indicate the existence of the power of metaphysical communication which is very relevant to use during the scouring of disruption that has built a sub-civilization that plays the role of digital cybernetic technology.
\end{abstract}

Keywords: Java; communication; metaphysic; disruption

\section{Introduction}

Communication is a term in English which has many meanings. Communication comes from Latin, which is communist (common) which turns into a verb: communicate "to spread or inform information to other parties in order to get the same meaning" [1]. Furthermore, Bialek \& Rieke explains that communication occurs when a source delivers a message to the recipient with a conscious intention to influence the recipient's behaviours [2].

Stoner stated "Communication is the process by which people attempt to share meaning via the transmission of symbolic messages [3]. The authors want to say a communication process that utilizes all potential, including symbolic potential. That is, communication can be done directly or indirectly, using various available communication media [4]. Direct communication means communication without a mediator or intermediary, whereas indirect communication means the opposite. In conclusion, communication is the process of transferring ideas from a source to one or more recipients with the intention of changing their behaviour.

In general, Javanese metaphysical understanding is implementing as a process of analysing the essence of the existence of something and the reality that accompanies it [5]. That is, metaphysical communication is a fairly broad field, including discussion of existence, 
actualization of communication, and communication. Metaphysical communication discusses an essential communication process, which is something that is substantive and fundamental. In addition, metaphysical communication also discusses the requirements and aspects of justification (ontology). And the last part is its use in dialogue or communication in society.

Metaphysical communication becomes very meaningful when dis-communication occurs. At least, if the communication ends with a dead lock caused by some parties not trying to understand each other. Gaps in communicating frequently occur between the elite and the public, resulting in a "movement" or unwanted activity. The ultimate result is the emergence of anarchism which is difficult to avoid. Research and dismantling of the communication process is necessary to obtain a new communication orientation. That is communication that can understand each other and have certain good goals.

Noonan touched on the meaning and importance of metaphysical communication in their book entitled "Identity" [6]. They both suspect that confusion will arise when the metaphysical communication model is not understood by both parties. However, such a thing can be explained by looking at its essence, its justifying element, and the reality of the value it appears to our senses. Therefore, this paper seeks to uncover the three damal perspectives of metaphysical communication. The results will be easy to use to see the implications of metaphysical communication in human life. According to Ayatrohaedi local wisdom is a national cultural identity / personality that causes the nation to be able to absorb and process foreign culture according to its own character and abilities [7].

\section{Research Methods}

The source of the writing is obtained from textual data in the form of Javanese aphorisms from various sources of old books and documents. The data were analyzed using content analysis methods and theories. Thus, the preparation of this paper is included in library research. To get the data validity also use triangulation models (sources, methods, theories, researchers) [8],[9]. This study uses data analysis qualitative by doing data reduction, data presentation, drawing conclusions / verification. The results are presented in a text-narrative manner with interactive analysis through the process of cycle form (continuous) [10].

\section{Results and Discussion}

\section{The Essence of Metaphysical Communication}

The essence of metaphysical communication in Javanese society is basically understood into three forms. First, metaphysical communication is basically understood as a communication process as a form of "mutual understanding". A good relationship and the purpose of communication will be achieved if it is based on mutual understanding, respect, and very good relationships which are based on ethical and moral values for the survival of life and civilization together. Metaphysical communication utilizes all means of human communication, namely: verbal, gesture, gesture, face, heart, feeling, suspicion, hope, etc., and tends to be more complete (holistic) than just physical communication (verbal and written).

Second, nguwongke. This term implies humanist meaning, which is "to make people feel like people" and refers to a close, dense, dense, spaced, equal, and beautiful relationship. In fact, it is more than the physical value of beauty [11]. The Javanese term nguwongke is very 
important to understand in the process of elite-public communication. Ki Ageng Surya Mataram in his book Pangawikan Pribadi (1985) wrote a famous sentence, namely Seprana-seprene aku ora nate ketemu uwong "I've never met anyone from a long time ago". If so, who had he met all this time? Isn't there people around him? What does this imply? This was the satire that he conveyed, inhuman things, dis-communication, and great moral decadence around him at that time.

Third, manggonke "puts something in a it places, right, safe, comfortable, and that's what it is". The term of manggonke is a form of acceptance of all foreign elements, different elements, incoming elements [12],[13]. Metaphysical communication is indispensable in times of conflict or disagreements that taper because it gives room for their own differences. Difference is not something that is painful, scary, to be avoided. In life there is a possibility of differences. It is possible to disagree over something even simple. Manggonke is a space for various differences that occur during communication.

\section{Terms and Basis of Javanese Metaphysical Communication Justification}

Javanese culture has so many strategies in communication practices. The terms and basis for the justification of metaphysical communication are in the form of principles, rules, strategies, and the law of politeness. The following are prerequisites and basic justifications in Javanese metaphysical communication.

a. The concept of triadic manners is the "concept of three modesty", namely santun ilat, glagat, caterpillar

b. Yitna yuwana, lena kena; Yatna yuwana, lena kena 'alert to safety, complacent will be harm'

c. I got iwake, ora buthek banyune "the fish was caught, the water was not cloudy"

d. Ora ndilat idune dhewe 'not licking her own saliva'

e. Kakeyan gludhug kurang udan 'too much talk doesn't work'

\section{Sensable Activity Value.}

Metaphysical communication is a concept of communication that is rife in Javanese culture. In practice, this concept is related to other elements of Javanese culture. At the axiological level, the sensable activity values of metaphysical communication are:

a. The birth of Unggah-ungguh

b. Respect

c. Pseudo Regent, Esem Mantri, Dhupak Bujang

d. Clothes

\section{Crucial Issues in Elite-Public Communication}

The current case around us on a national, and even world scale, is the Covid-19 pandemic. What a great threat looms right in front of us. Hundreds of thousands of people died, even millions of them, around the world. The impact of the Covid 19 pandemic has been tremendous for the order of life in the world. More than 230 countries struggle in the health, economic, social and cultural fields. The scenario of Modernism is unprepared (stutters) for the effects of a pandemic. Nobody knows the end of this pandemic story. While many people are confused.

The government is trying hard to deal with the impact of the Covid 19 pandemic by mobilizing all the strength of the nation. Of course, things did not go easy. There are parties who take advantage of this opportunity for interests that are not at all good. So the news about the corruption of covid aid funds emerged, some were playing in the midst of suffering, some still didn't understand this situation. From a communication point of view, it was found that there were differences in the communication logic between the elite and the public. 
1. Elites usually use the ontology of metaphysical logic in communicative interactions with the public. As a result, the choice of this communication model has drawn criticism from the public who think that: the government is not open enough, the delivery of information is not measurable, it is less realistic, and so on.

2. The public tends to use a physical communication model with pragmatic logic. Everything is always measured by single truth 'single truth' without giving room to other perspectives and world views. On the surface, the public is often seen choosing what is beneficial for themselves, which can be used alone, involved alone, feels encouraged, feels used, etc.

This difference in communication logic is a source of dis-communication between the elite and the public. The two of them do not practice the principles of mutual understanding, mutual understanding, and mutual awareness. Each of them tries to wait for karepe dhewe to "believe in his own will" without paying attention to the other because he feels he holds his own truth. The two sides did not present a "waiting room" for the dialectic of politics, social, humanities, culture, language and communication between the elite and the public.

\section{Conclusion}

Metaphysical communication can be an option amid the frequency of dialogue between the elite and the public is often disrupted. In unfavourable situations, the choice of form of communication should be appropriate, namely communication that reaches physical and nonphysical things. In the context of system development, support from other sectors is needed, namely the Crocodile Tradition. Why? The cultural tradition teaches cosmosentric awareness, the awareness that humans are part of nature who have clear rights and obligations, memayu hayuning bawana "to beautify the beauty of nature (covert and overt)". So the choice of the word is "bawana" and not "buwana" because buwana only refers to the physical. Countries that have developed cultural traditions as a counterweight are Japan, India, China and Singapore.

In Additions, for an indefinite period of time, the basic principles of politeness in communication should be of concern to all elements of the country. The developing country is not marked by an increase in towering buildings, wide and smooth and bright roads. But also, by the increasing quality of society and citizens who are more polite, more friendly, more obedient, more loyal to their government.

Javanese culture knows adegium, winning without ngasorake "winning without beating". This is the ultimate most powerful weapon. The end of the physical war is rapidly moving towards other wars, including economic war, cultural war, and finally we are with a proxy war. Modern wars do not involve many people, as if they do not show violence, but take enormous casualties. Modern warfare is not only physically threatening, but also psychologically to the fetuses of babies still in their mother's womb. So, this is the time for the development of metaphysical communication to be chosen to be developed.

\section{References}

[1] Ruben, B. D. (2015). Intercultural communication competence in retrospect: Who would have guessed? International Journal of Intercultural Relations, 48, 22-23. https://doi.org/https://doi.org/10.1016/j.ijintrel.2015.03.010

[2] Bialek, W., \& Rieke, F. (1992). Reliability and information transmission in spiking neurons. In Trends in Neurosciences. https://doi.org/10.1016/0166-2236(92)90005-S 
[3] Stoner, J. A. F. and R. E. F. (2015). Jurnal 12. In Management.

[4] Bonny, E., \& Berkes, F. (2008). Communicating traditional environmental knowledge: addressing the diversity of knowledge, audiences and media types. Polar Record. https://doi.org/10.1017/S0032247408007420

[5] Novarina, N. (2020). Pandhawa Gubah sebagai Representasi Interaksi Metafisik Manusia Jawa dan Perbandinganny dengan Cheritera Pandawa Lima. Manuskripta. https://doi.org/10.33656/manuskripta.v10i1.142

[6] Noonan, Harold and Curtis, B. (2018). Identity (Edward N. Zalta (ed.); Summer). Metaphysics Research Lab, Stanford University

[7] Ayatrohaedi.1986. Kepribadian Budaya Bangsa (local Genius.,Jakarta: Pustaka Jaya

[8] Koentjaraningrat. (1977). Metode-Metode Penelitian Mayarakat.Jakarta: PT. Gramedia Pustaka Utama

[9] Moleong, Lexy J. (1989). Metodologi Penelitian Kualitatif. Bandung: PT. Remaja Rosdakarya

[10] [Sutopo, H.B. (1986). Metode Penelitian Kualitatif. Surakarta: Penerbit Universitas Sebelas Maret

[11] Hidayatullah, M. Furqon. (2010). Pendidikan Karakter: Membangun Peradaban Bangsa. Surakarta: Yuma Pustaka

[12] Megawangi, Ratna. (2004). Pendidikan Karakter: Solusi yang Tepat untuk Membangun Bangsa. Jakarta: Indonesia Heritage Foundation

[13] Zultom, A. (ed.). (1984). Budaya Sastra. Jakarta: Rajawali. 